\title{
KÖNNYÜ ADALÉKANYAG FELHASZNÁLÁSÁVAL KÉSZÍTETT TÉGLAIPARI TERMÉKEK VIZSGÁLATA
}

\author{
Hamza Alexandra \\ tanszéki mérnök, Korszerü Anyagok és Intelligens Technológiák \\ Felsőoktatási és Ipari Együttmüködési Központ \\ 3515 Miskolc, Miskolc-Egyetemváros, e-mail: femhamza@uni-miskolc.hu \\ Kocserha István \\ egyetemi docens, Miskolci Egyetem, Kerámia- és Polimermérnöki Intézet \\ 3515 Miskolc, Miskolc-Egyetemváros, e-mail: istvan.kocserha@uni-miskolc.hu
}

\begin{abstract}
Absztrakt
Ebben a tanulmányban duzzasztott perlit téglaipari alkalmazhatóságát és a késztermék tulajdonságaira gyakorolt hatását vizsgáltuk. Ez az adalékanyag az épitöipar más területén, mint például a könnyübeton gyártás széles körben elterjedt kiváló höszigetelö tulajdonsága miatt. A kísérletekhez agyagmasszákat készitettünk laboratóriumi kollerjárat alkalmazásával, a masszák nedvességtartalma $25 \mathrm{~m} / \mathrm{m} \%$ volt minden esetben. A perlit bekeverésének arányát 2,5-6,5 $\mathrm{m} / \mathrm{m} \%$ között változtattuk. A masszákból hengeres próbatesteket készitettünk vákuum extruderrel, majd $880^{\circ} \mathrm{C}$-on $140^{\circ} \mathrm{C}$ felfütési sebességgel kiégettük. A kiégetett próbatestek testsürüsége $1855-1695 \mathrm{~kg} / \mathrm{m}^{3} \mathrm{között} \mathrm{változott} \mathrm{a} \mathrm{perlit} \mathrm{bekeverési} \mathrm{arányának}$ emelésével. Az adalékanyag nélkül készitett minták átlag nyomószilárdsága $32 \mathrm{MPa}$ volt, a perlit bekeverésével ez az érték 27 MPa körüli értékekre csökkent. A perlit bekeverési mennyiségének növelése nem eredményezett jelentős nyomószilárdság csökkenést. Ezzel szemben a szerves pórusképzö adalékanyagok esetében ez egy általános probléma, amely korlátot szab ezen adalékanyagok bekeverési mennyiségének.
\end{abstract}

Kulcsszavak: agyag, duzzasztott perlit, nyomószilárdság, téglagyártás

\begin{abstract}
In this study, the effect of expanded perlite on performance of fired clay bricks was investigated. This additive material is in other areas of the construction industry such as lightweight concrete production in use. The reason for its popularity is based on the excellent thermal insulation properties of expanded perlite. During the experiments different clay masses were prepared by pan mill. Moisture content of the clay masses was set to $25 \mathrm{wt} \%$ in each case. The amount of expanded perlite was varied between 2.5-6.5wt\%. Cylindrical samples were prepared by a laboratory vacuum extruder and then the dried samples were sintered in a laboratory furnace at $880^{\circ} \mathrm{C}$. Results showed that density of fired samples decreased from 1855 to $1695 \mathrm{~kg} / \mathrm{m}^{3}$ by increasing the amount of the perlite. Samples without perlite had an average compressive strength of $32 \mathrm{MPa}$ which decreased down to $27 \mathrm{MPa}$ with the mixing of perlite. Amount of perlite had no relevant effects on compressive strength. This in contrast the organic poreforming additives cause significantly lower the compressive strength.
\end{abstract}

Keywords: brick production, clay, compressive streng, expanded perlite 


\section{Bevezetés}

Az égetett tégla az egyik legrégibb épitőanyag, amely agyagból, vízből és egyéb adalékanyagokból készül. A kiégetett téglák testsürüsége, porozitása, mechanikai szilárdsága és színe függ az alkalmazott alapanyagok ásványtani összetételétől és az égetési hőmérséklettől [1,2]. A tégla alapvetően egy tömörre égő, nagy mechanikai szilárdságú, rossz szigetelő tulajdonságokkal rendelkező kerámia. A hőszigetelő képesség javítása érdekében pórusképző adalékanyagokat kevernek az agyagmasszához, amelyek a hőkezelés következtében kiégnek, ezzel növelve a porozitást az égetett agyagmátrixban [3]. A leggyakrabban alkalmazott szerves adalékanyag a fürészpor, mindemellett kutatásokat folytatnak egyéb adalékok alkalmazásával kapcsolatban is, mint például a napraforgó maghéj, rizshéj illetve a borászatból keletkezett melléktermékek [4,5,6]. Számos szakirodalomban foglalkoztak a szerves pórusképző adalékanyagok azon mennyiségének meghatározásával, amely nem okoz jelentős nyomószilárdság csökkenést. A tanulmányokban arra a következtetésre jutottak, hogy a szerves adalékanyagok $10 \mathrm{~m} / \mathrm{m} \%$ tól nagyobb mértékủ hozzáadása nem ajánlott, hiszen ettől nagyobb mennyiség bekeverése jelentős nyomószilárdság csökkenéshez vezet $[7,8,9,10]$.

A duzzasztott perlit azonban a téglagyártás hőmérsékletén stabil marad, nem távozik a termékből, így a nyomószilárdságot kevésbé rontja, mint az általánosságban alkalmazott szerves adalékanyagok [11,12].

A perlit nem más, mint egy hidratált vulkáni üveg, amely obszidiánok másodlagos alternatívájaként képződik, melynek során vizet épít be üvegszilika szerkezetébe. A perlit magas $\mathrm{SiO}_{2}$ tartalmú, alacsony lágyulási ponttal rendelkezik, ezt kihasználva készítenek az építöipar számára is alkalmazható könnyüadalékanyagot $[13,14,15]$. A kibányászott perlit kőzetet hirtelen hevítéssel $900-1200^{\circ} \mathrm{C}$-ra melegítik, ennek hatására a perlit piroplasztikus állapotba kerül. A magas hőmérséklet hatására keletkezett gázok az eredeti térfogatához képest 5-20-szorosára növelik [16,17]. A térfogat növekedés következtében a perlit egy alacsony testsürüségü $\left(32-200 \mathrm{~kg} / \mathrm{m}^{3}\right)$, nagy porozitású anyaggá alakul, amelyet duzzasztott perlitnek nevezünk [18]. A kialakult szerkezet kiváló hőszigetelési tulajdonságokat $(0,040-0,055 \mathrm{~W} / \mathrm{m} \cdot \mathrm{K})$ és magas porozitást biztosít, mindemellett nyitott cellás szerkezetének köszönhetően jó hangszigetelö tulajdonságokkal rendelkezik [18,19,20]. A duzzasztott perlitet alkalmazzák könnyübetonok, hőszigetelő vakolatok, valamint égetett kerámiatermékek üregeinek kitöltéséhez, ezzel javítva az építőanyagok energetikai tulajdonságait [21].

Ebben a tanulmányban azt vizsgáltuk, hogy a duzzasztott perlit bekeverése milyen hatást gyakorol a téglatermékek egyes tulajdonságaira, mint például a száradási és égetési zsugorodásra, vízfelvételre valamint a nyomószilárdságra. A vizsgálatok elvégzéséhez a duzzasztott perlit bekeverési mennyiségének módosításával 6 különbözö masszát készítettünk, melyekben a perlit mennyiségét a száraz agyagkeverék tömegéhez viszonyítva 2,5-6,5 $\mathrm{m} / \mathrm{m} \%$-ban adagoltuk.

\section{Alapanyag vizsgálat, próbatestek elkészítésének menete}

\subsection{Agyagok röntgen pordiffrakciós analízise}

A kísérletünkhöz agyagmassza elkészítéséhez szürke és sárga agyag együttes keverékét használtuk. Mindkét agyag esetében megvizsgáltuk az ásványi összetételt röntgen pordiffrakcióval (Rigaku Miniflex II, $\mathrm{Cu} \mathrm{K} \alpha, 2 \theta$ tartományban 3-90\%). A mérés alapján azonosított ásványok százalékos mennyiségét az 1. táblázatban foglaltuk össze. Az eredményként kapott ásványi összetétel alapján megállapítható, hogy a szürke agyag zsírosabb a sárga agyaghoz viszonyítva, ami azt jelenti, hogy nagyobb mennyiségben találhatóak meg benne az agyagásványok. A szürke agyag ásványanyag tartalma $45 \mathrm{~m} / \mathrm{m} \%$, míg ez a szám a sárga agyag esetében $35 \mathrm{~m} / \mathrm{m} \%$. 
1. táblázat. Agyagok ásványanyag összetétele

\begin{tabular}{cccc}
\hline \multirow{2}{*}{ Ásvány } & \multirow{2}{*}{ Ásványtípus } & Szürke agyag & Sárga agyag \\
\cline { 2 - 4 } & & Mennyiség a kristályos fázison belül (m/m\%) \\
\hline Kvarc & Kvarc & 33,13 & 36,85 \\
\hline Illit & Agyagásvány & 21,88 & 18,44 \\
\hline Muszkovit & Csillám & 9,18 & 4,83 \\
\hline Albit & Földpát & 8,96 & 12,22 \\
\hline Szmektit & Agyagásvány & 5,69 & 2,12 \\
\hline Götit & Vas-hidroxid & 0,00 & 0,66 \\
\hline Kaolin & Agyagásvány & 4,48 & 3,42 \\
\hline Illit szmektit & Agyagásvány kevert fázis & 0,89 & 0,83 \\
\hline Rutil & Titánoxid & 0,79 & 0,74 \\
\hline Klorit & Agyagásvány & 3,94 & 6,72 \\
\hline Mikroklin & Káliföldpát & 2,08 & 0,58 \\
\hline Kalcit & Karbonát & 1,00 & 5,35 \\
\hline Ortoklász & Káliföldpát & 0,00 & 1,47 \\
\hline Dolomit & Karbonát & 0,00 & 2,78 \\
\hline Amorf & Amorf & 8,00 & 3,00 \\
\hline
\end{tabular}

\subsection{Agyagok termoanalitikai vizsgálata}

Az alkalmazott szürke és sárga agyagon termoanalitikai vizsgálatot végeztünk, ezzel további információkat kaptunk az agyagokat alkotó ásványokról, illetve azok módosulatairól. A vizsgálathoz bemért minta mennyisége mind két agyag esetében $250 \mathrm{~g}$ volt. A vizsgálat hömérséklet tartománya $35-1000{ }^{\circ} \mathrm{C}$ volt, melyhez $10{ }^{\circ} \mathrm{C} /$ perc felfútési sebességet alkalmaztunk. Az elemzés során a TG görbe mutatja a hevítés hatására bekövetkező tömegváltozást, a DTG ennek intenzitását, illetve a DTA arra utal, hogy a lejátszódó folyamat exoterm, vagy endoterm jellegü.

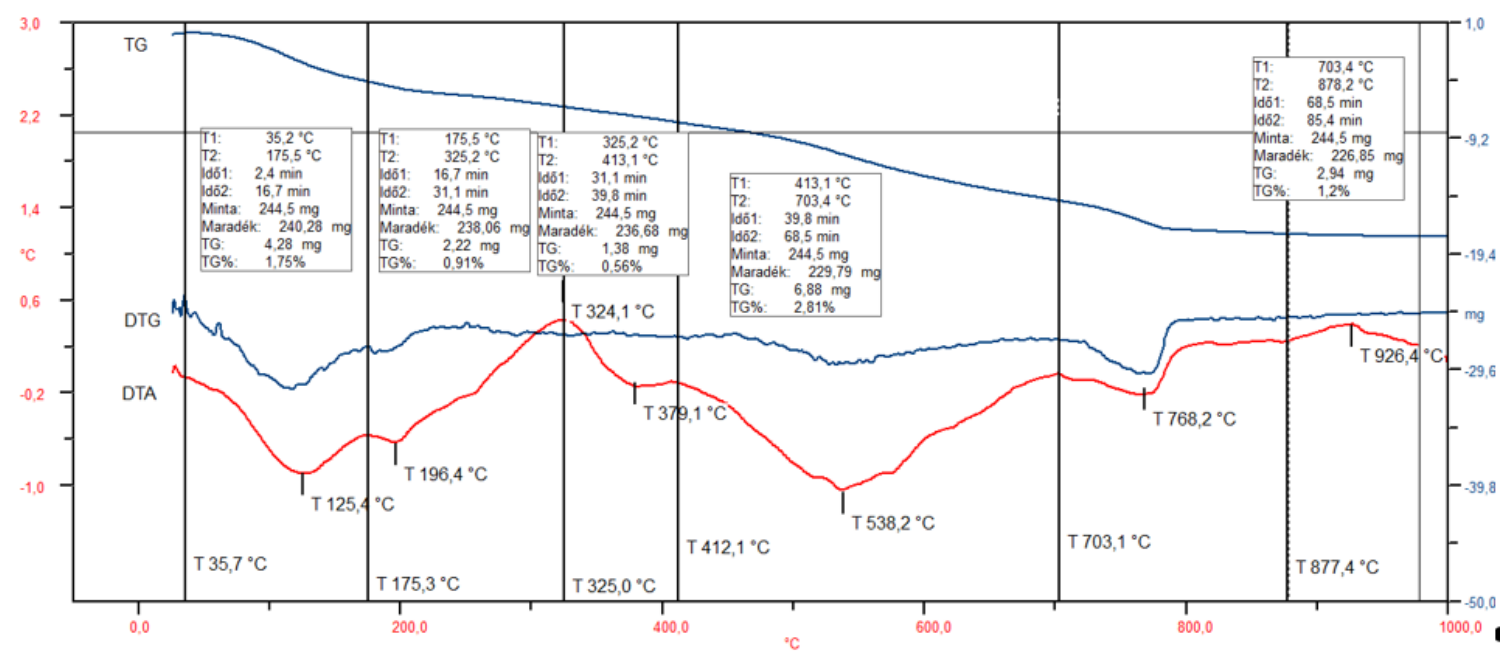

1. ábra. Szürke agyag derivatogramja 
Az 1. ábrán látható diagram első endoterm csúcsa $125,4{ }^{\circ} \mathrm{C}$ körül volt megfigyelhető, amely az ásványok felületén, illetve a montmorillonit által megkötött higroszkópikus víz különböző rétegeiböl történő távozását mutatta. A következő endoterm csúcs $196,4^{\circ} \mathrm{C}$ körül volt, ami a Ca-montmorillonitra és a vermikulitra is egyaránt jellemző. A 196,4 ${ }^{\circ} \mathrm{C}$-nál látható endoterm csúcs az amorf tartalomban lévő alumínium és vas-oxid-hidrátok bomlására is utalhat. $324,1{ }^{\circ} \mathrm{C}$-nál egy exoterm csúcs látható, ami a wüstitre jellemzö, amely viszonylag alacsony hömérsékleten oxidáció következtében hematittá alakul. $412{ }^{\circ} \mathrm{C}$ hömérsékleten ismét megindult egy endoterm folyamat, melynek oka a hidrátvizek, illit rétegvizeinek távozásának és a kaolin dehidratációjának kezdete. A kaolin esetében $538{ }^{\circ} \mathrm{C}$ körül lezárult ez a folyamat melynek következtében metakaolin keletkezett. A következő endoterm csúcs $770{ }^{\circ} \mathrm{C}$-nál megfigyelhető, ezen a hőmérsékleten megkezdődött a muszkovit dehidratációja [22].

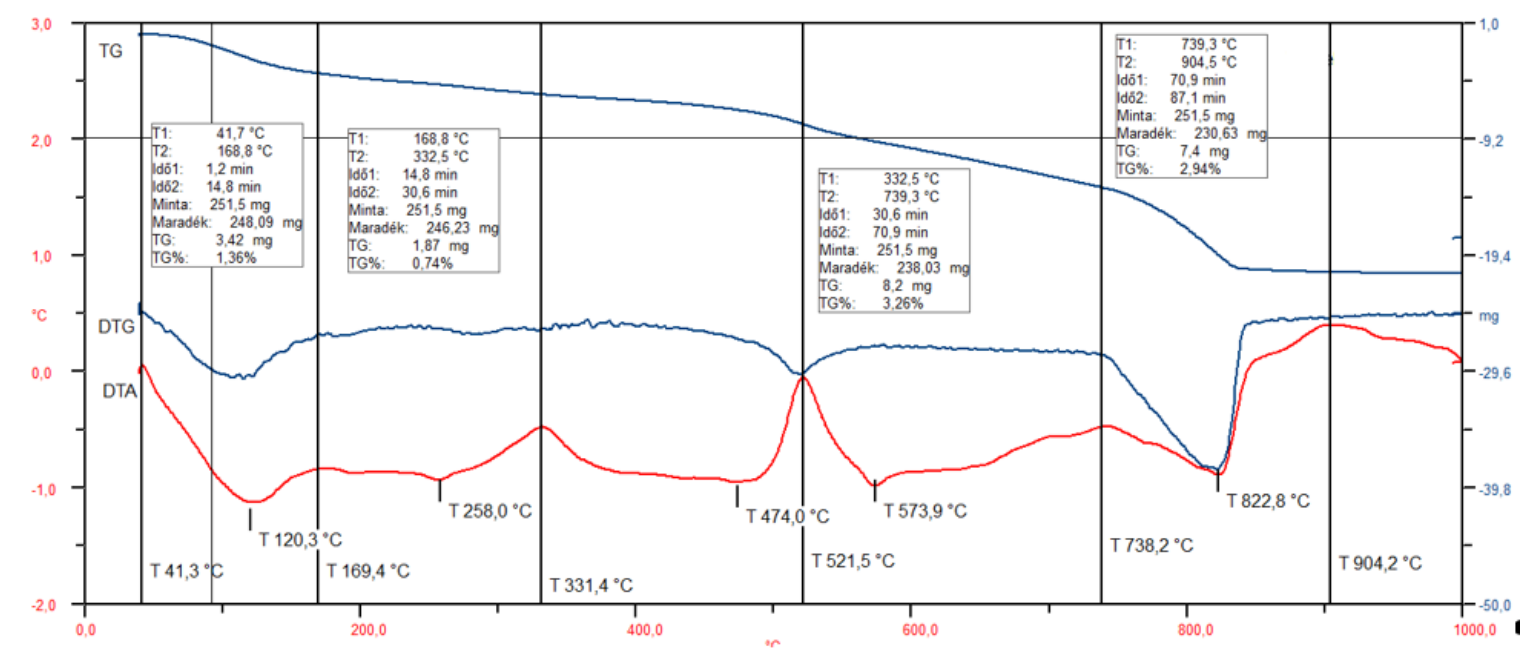

2.ábra. Sárga agyag derivatogramja

Az XRD analízis alapján jól látható, hogy a két agyag ásványi összetétele hasonló, nagyrészt mennyiségi eltérések figyelhetőek meg, ebböl adódik, hogy a termoanalitikai vizsgálatban sem voltak nagyobb eltérések. Az első különbség a sárga agyagban a $521,5^{\circ} \mathrm{C}$-nál volt megfigyelhető. Ezen a hőmérsékleten egy exoterm csúcs látható, amely a lepidokrokit $\gamma-\mathrm{FeO}(\mathrm{OH})$ jelenlétét mutatta. A lepidokrokit és a goetit kémiai összetétele megegyezik. A különbség, hogy a lepidokrokit bomlása alacsonyabb hömérsékleten $360-370{ }^{\circ} \mathrm{C}$-on kezdődik. A lepidokrokit hevítés hatására elveszti, $\mathrm{OH}$ gyökeit, melynek következtében $\gamma-\mathrm{Fe}_{2} \mathrm{O}_{3}$ lesz belőle, ami egy $521^{\circ} \mathrm{C}$-nál lévő exoterm folyamat következtében $\alpha-\mathrm{Fe}_{2} \mathrm{O}_{3}$-á alakul. A jelentős tömegcsökkenés a dolomit lépcsőzetes bomlásával magyarázható, mert jellemzően ebben a hőmérséklet tartományban a $\mathrm{CaMg}\left(\mathrm{CO}_{3}\right)$ dekarbonizációja megindult, melynek következtében MgO keletkezett egy intenzív tömegcsökkenés kíséretében. 823 ${ }^{\circ} \mathrm{C}$-nál újra endoterm csúcs figyelhető meg, amely szintén jelentős tömegcsökkenést eredményezett, ezen a hőmérsékleten megindult a dolomit másik alkotójának a kalcitnak a bomlása [22].

\subsection{Próbatestek elkészítése}

A próbatestek elkészítéséhez használt agyagmasszához, a szürke és sárga agyagokat 1:1 arányban alkalmaztuk, az adalékanyagként hozzáadott duzzasztott perlit mennyiségét 2,5-6,5 $\mathrm{m} / \mathrm{m} \%$-ban adagoltuk a masszákhoz. Az agyagkeverékek elkészítését megelőzően az agyagokat $50{ }^{\circ} \mathrm{C}$-on tömegállandóságig szárítottuk a pontos nedvességtartalom beállításának megkönnyítése érdekében. A száraz alapanyagokat laboratóriumi kollerjárat segítségével homogenizáltuk, ezt követően fokozatos adagolás mellett hozzáadtuk a formázáshoz 
szükséges víz mennyiségét, amely minden massza esetében a száraz anyagra vonatkoztatva $25 \mathrm{~m} / \mathrm{m} \%$ volt. A megfelelően homogenizált agyagmasszákat légmentesen elzártuk, majd 24 órás pihentetést követően, laboratóriumi vákuum extruderrel (KEMA PVP 5/s) 24 mm átméröjü $50 \mathrm{~mm}$ magasságú hengeres próbatesteket készítettünk. A masszák jelölésrendszerét a 2.táblázatban ismertettük.

2. táblázat. Masszák összetétele

\begin{tabular}{crrrrr}
\hline \multirow{2}{*}{ Massza } & \multicolumn{2}{c}{ Duzzasztott perlit mennyisége } & Szürke agyag & Sárga agyag & Víz \\
\cline { 2 - 6 } & {$[\mathrm{m} / \mathrm{m} \%]$} & {$[\mathrm{g}]$} & {$[\mathrm{g}]$} & {$[\mathrm{g}]$} & {$[\mathrm{g}]$} \\
\hline $\mathrm{R}$ & 0 & 0 & 1500,0 & 1500,0 & 750 \\
\hline DP1 & 2,5 & 75 & 1462,5 & 1462,5 & 750 \\
\hline DP2 & 3,5 & 105 & 1447,5 & 1447,5 & 750 \\
\hline DP3 & 4,5 & 135 & 1432,5 & 1432,5 & 750 \\
\hline DP4 & 5,5 & 165 & 1417,5 & 1417,5 & 750 \\
\hline DP5 & 6,5 & 195 & 1402,5 & 1402,5 & 750 \\
\hline
\end{tabular}

\section{Laboratóriumi vizsgálatok és eredmények}

\subsection{Száradási és égetési zsugorodás}

A próbatesteket az extrudálás után 24 órán keresztül szabad levegőn, majd labortóriumi szárítószekrényben $105{ }^{\circ} \mathrm{C}$-on 48 órán keresztül tömegállandóságig szárítottuk. Ezt követően $140{ }^{\circ} \mathrm{C} / \mathrm{h}$ felfütési sebességgel $880^{\circ} \mathrm{C}$-on 30 perces hőntartással kiégettük. A száradás és égetés hatására bekövetkező méretváltozás meghatározása érdekében a minden próbatest átmérőjét és magasságát megmértük nyers, szárított és égetett állapotban is. A mért adatok ismeretében kiszámítottuk a száradási (3. ábra) és égetési térfogatzsugorodást (4. ábra).

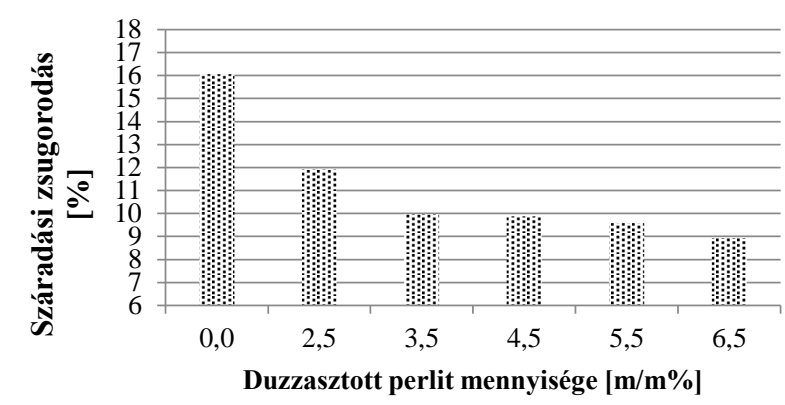

3. ábra. Száradási zsugorodás

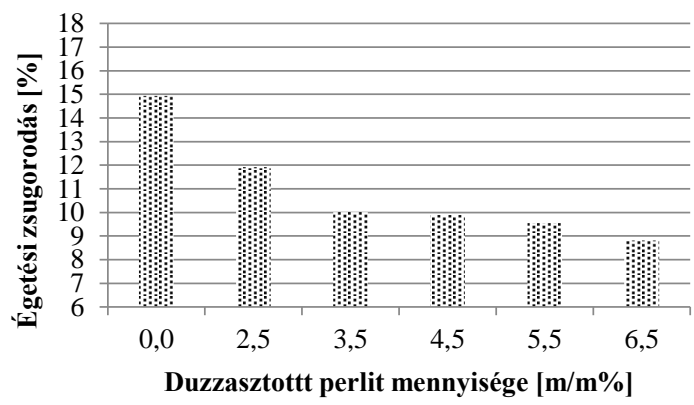

4. ábra. Égetési zsugorodás

Az eredmények alapján megállapítható, hogy a száradási és égetési zsugorodás esetében csökkentő tendencia volt megfigyelhető a duzzasztott perlit mennyiségének növelésével. A száradási és égetési zsugorodás értékeit összevetve az eredmények azt mutatták, hogy a minták a szárítást követően a kiégetés során csak kis mértékben zsugorodtak.

\subsection{Testsürüség meghatározása}

A minták testsürüségének méréséhez hidrosztatikai módszert használtunk, ami Archimédesz törvényén alapszik. A mérést ebben az esetben beállításonként $5 \mathrm{db}$ kiégetett mintán végeztük el, melyeket 105 
${ }^{\circ} \mathrm{C}$-on tömegállandóságig szárítottunk. A mérési eredményeket százalékosan hasonlítottuk össze, referenciának a duzzasztott perlit nélkül készített minták értékeit tekintettük. A mért testsürüségek pontos értékeit a 3. táblázatban foglaltuk össze.

3. táblázat. Próbatestek testsürüsége

\begin{tabular}{lcccccc}
\hline Massza azonosítója & $\mathrm{R}$ & $\mathrm{DP} 1$ & $\mathrm{DP} 2$ & $\mathrm{DP} 3$ & DP4 & DP5 \\
\hline Testsürüség $\left[\mathrm{kg} / \mathrm{m}^{3}\right]$ & 1855 & 1755 & 1734 & 1715 & 1705 & 1696 \\
\hline Testsürüuég a referenciához viszonyítva [\%] & 100 & 94,61 & 93,49 & 92,49 & 91,94 & 91,45 \\
\hline
\end{tabular}

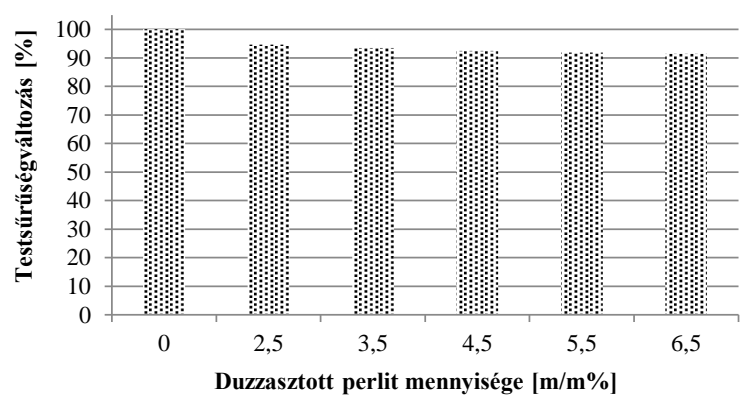

5. ábra. Testsürüség változása a perlit tartalom függvényében

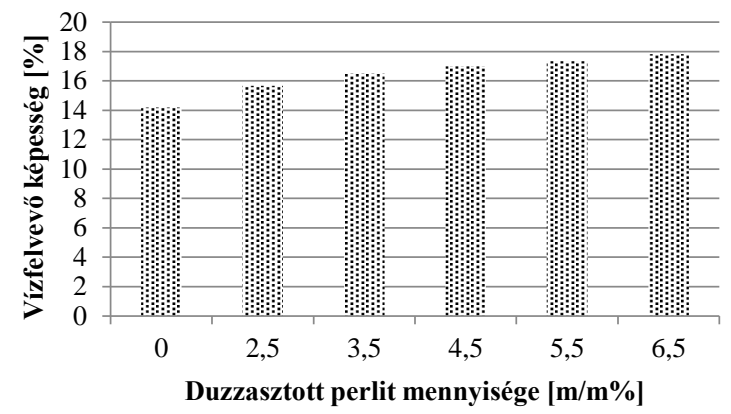

6. ábra. Vizfelvevö képesség

Az 5. ábra grafikusan ábrázolja a minták testsürüségének változását, az ábrázoláshoz a referencia (duzzasztott perlit mentes) próbatestek átlagértékét tekintettük, majd ehhez képest ábrázoltuk a testsürüségek csökkenését a duzzasztott perlit mennyiségének függvényében. Az adalékanyag bekeverésével a testsürüség értéke csökkenést mutatott, amely a hozzáadott mennyiség növelésével további csökkenést eredményezett.

\subsection{Vízfelvevő képesség vizsgálata}

A vízfelvevő képességet 10 db próbatesten mért eredmények átlagolásával számítottuk ki. A kiégetett mintákat egy vízzel teli edénybe helyeztük, majd a vizet forralásig hevítettük, ezt követően 4 órán keresztül forraltuk. A próbatestek száraz és vízzel telített tömegéböl kiszámoltuk a nyitott pórusokban jelenlévő víz mennyiségét. A 6. ábra alapján elmondható, hogy a duzzasztott perlit bekeverésével a próbatestek vízfelvétele növekvő tendenciát mutatott. A perlitben a duzzasztás hatására apró pórusok keletkeznek, amely nagyrészt nyitott cellás szerkezetet eredményez, ezáltal magas vízfelvevő képességgel rendelkezik. Ennek eredményeként a perlit mennyiségének emelésével nött a minták vízfelvétele.

\subsection{Nyomószilárdság vizsgálat}

A nyomószilárdság vizsgálatokat masszánként $10 \mathrm{db}$ kiégetett mintán végeztük el egy mechanikus 10 t méréshatárral rendelkező mechanikus törőberendezéssel. A vizsgálatot $24 \mathrm{~mm}$ átmérővel és $50 \mathrm{~mm}$ magassággal rendelkező próbatesteken vizsgáltuk. A mérést megelőzően a minták felületeit párhuzamosítottuk, a pontosabb mérési eredmények érdekében. Az eredményeket a 7. ábrán szemléltettük. A diagram alapján megállapítható, hogy a duzzasztott perlit nélkül készített referencia minták átlag nyomószilárdsága 31,98 MPa volt, 2,5 m/m\% perlit bekeverésével ez 26,62 MPa-ra csökkent. A perlit mennyiségének további emelése nem mutatott jelentős eltérést, mindemellett $3,5 \mathrm{~m} / \mathrm{m} \%$ perlit mennyiségtől minimális növekedés figyelhetö meg a $2,5 \mathrm{~m} / \mathrm{m} \%$-hoz képest. 


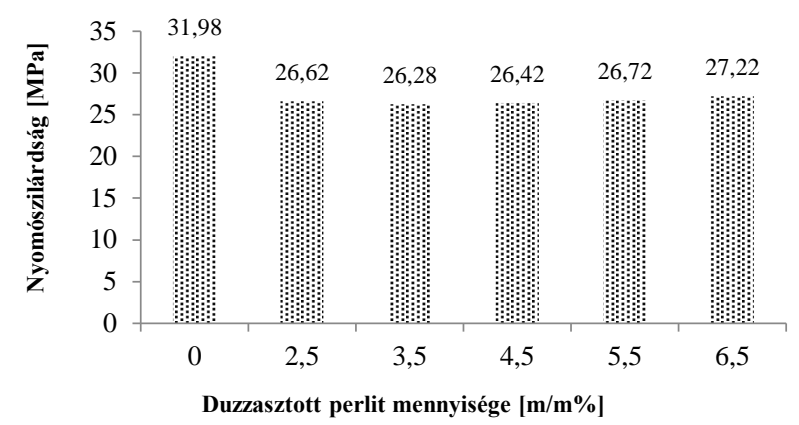

7. ábra. Nyomószilárdság változása a duzzasztott perlit mennyiségének függvényében

\section{4. Összegzés}

Az általunk elvégzett vizsgálatok alapján elmondható, hogy a duzzasztott perlit összeségében pozitív hatást gyakorol egyes tulajdonságokra, mint például a száradási zsugorodásra és a nyomószilárdságra. A száradási zsugorodás a perlit nélkül készített minták esetében $16 \%$ volt, ez az érték $6,5 \mathrm{~m} / \mathrm{m} \%$ duzzasztott perlit bekeverésével $9 \%$-ra csökkent, ez technológiai szempontból kedvező, hiszen méretpontosabb termékek készíthetőek. A testsürüség esetében a duzzasztott perlit mennyiségének emelésével fokozatos csökkenés volt megfigyelhetö, ezzel szemben a nyomószilárdság a testürüség csökkenésével nem csökkent jelentősen. A nyomószilárdság a referencia mintához képest $32 \mathrm{MPa}$-ról $2,5 \mathrm{~m} / \mathrm{m} \%$ bekeverésével 26,7 MPa-ra csökkent, amely a perlit bekeverési arányának emelésével nem mutatott további jelentős csökkenést. A próbatestek vízfelvevő képessége az adalékanyag mennyiségének növelésével emelkedést mutatott, ez a duzzasztott perlit nyitott cellás szerkezetével magyarázható.

\section{Köszönetnyilvánítás}

A tanulmányban ismertetett kutató munka az EFOP-3.6.1-16-2016-00011 jelü „Fiatalodó és Megújuló Egyetem - Innovatív Tudásváros - a Miskolci Egyetem intelligens szakosodást szolgáló intézményi fejlesztése" projekt részeként - a Széchenyi 2020 keretében - az Európai Unió támogatásával, az Európai Szociális Alap társfinanszírozásával valósul meg.

\section{Irodalom}

[1] Gömze, L. A., Gömze, L. N., Kurovics, E., Benedek, Gy.: Conventional brick clays as a challenge of materials science - New explanation of drying sensitivities, IOP Conf. Series: Materials Science and Engineering 613 (2019) 012005 https://doi.org/10.1088/1757-899X/613/1/012005

[2] Jamal Eldin, F. M., Ibrahim, D., Shushkov, E., Kurovics, M., Tihtih, O., Kotova, B., Pala, P. K., Gömze, L. A.: Effect of composition and sintering temperature on thermal properties of Zeolite-Alumina Composite Materials, Epitoanyag Journal of Silicate Based and Composite Materials 72(4):131 https://doi.org/10.14382/epitoanyag-jsbcm.2020.21

[3] Kocserha, I., Gömze, L. A., Kristály, F., Géber, R., Györffiy, B.: Effect of organic additives on friction properties of clay based compounds, Materials Science Forum Vol. 729 (2013) pp. 403-408. https://doi.org/10.4028/www.scientific.net/MSF.729.403 
[4] Kizinieviča, O., Kizinievič, V., Pundiene, I., Molotokas, D.: Eco-friendly fired clay brick manufactured with agricultural solid waste, Archives of Civil and Mechanical Engineering V. 18, Issue 4, September (2018) pp. 1156-1165. https://doi.org/10.1016/j.acme.2018.03.003

[5] Muñoz, P., Mendívil, M. A., Letelier, V., Morales, M. P.: Thermal and mechanical properties of fired clay bricks made by using grapevine shoots as pore forming agent. Influence of particle size and percentage of replacement, Construction and Building Materials 224 (2019) pp. 639-658. https://doi.org/10.1016/j.conbuildmat.2019.07.066

[6] Cultrone, G., Aurrekoetxea, I., Casado, C., Arizzi, A.: Sawdust recycling in the production of lightweight bricks: How the amount of additive and the firing temperature influence the physical properties of the bricks, Construction and Building Materials Vol. 235, 28 February 2020, 117436 https://doi.org/10.1016/j.conbuildmat.2019.117436

[7] La Rubia-García, M. D., Yerbe-Rodríguez, Á., Eliche-Quesada, D., Francisco, A., Corpas-Iglesias, López-Galindo, A.: Assessment of olive mill solid residue (pomace) as an additive in lightweightbrick productio, Construction and Building Materials 36 (2012) pp. 495-500.

https://doi.org/10.1016/j.conbuildmat.2012.06.009

[8] Taurino, R., Ferretti, D., Cattani, L., Bozzoli, F., Bondioli, F.: Lightweight clay bricks manufactured by using locally available wine industry waste, Journal of Building Engineering V. 26, Nov. (2019) 100892 https://doi.org/10.1016/j.jobe.2019.100892

[9] Neves Monteiro, S., FontesVieira, C. M.: On the production of fired clay bricks from waste materials: A critical update, Construction and Building Materials Vol. 68, 15 October (2014) pp. 599-610. https://doi.org/10.1016/j.conbuildmat.2014.07.006

[10] Sutcu, M., Akkurt, S., Bayram, A., Uluca, U.: Production of anorthite refractory insulating firebrick from mixtures of clay and recycled paper waste with sawdust addition, Ceramics International Vol. 38, (2012) pp. 1003-1041. https://doi.org/10.1016/j.ceramint.2011.08.027

[11] Sadik, C., Albizane, A., Amrani, I. E.: Production of porous firebrick from mixtures of clay and recycled refractory waste with expanded perlite addition, J. Mater. Environ. Sci. 4 (6) (2013) pp. 981-986.

[12] Hamza, A., Kocserha, I.: The effect of expanded perlite on fired clay bricks, Journal of Physics: Conference Series 1527, (2020) 012032 https://doi.org/10.1088/1742-6596/1527/1/012032

[13] Alaa M. Rashad: A synopsis about perlite as building material, A best practice guide for Civil Engineer, Construction and Building Materials Vol. 121, 15 September (2016) pp. 338-353. https://doi.org/10.1016/j.conbuildmat.2016.06.001

[14] Tapan, M., Engin, C.: Effect of Expanded Perlite Aggregate Size on Physical and Mechanical Properties of Ultra Lightweight Concrete Produced with Expanded Perlite Aggregate, Periodica Polytechnica Civil Engineering 63 (3), (2019) pp. 845-855. https://doi.org/10.3311/PPci.12680

[15] Jamei, M., Guiras, H., Chtourou, Y., Kallel, A., Romero, E., Georgopoulos, I.: Water retention properties of perlite as a material with crushable soft particles, Engineering Geology 122 (3), (2011) pp. 261-271. https://doi.org/10.1016/j.enggeo.2011.06.005

[16] Donald, F., Gunning, P. Eng.: Perlite market study report, Gunning and McNeal Associates Ltd., Crown Publications Inc.; 1994. p. 2-8.

[17] Abdelfattah, M., Kocserha, I., Géber, R., Tihtih, M., Móricz, F.: Evaluating the properties and mineral phases of the expanded clay aggregates with the bentonite additive material, Journal of Physics: Conference Series1527 (2020) 012030 https://doi.org/10.1088/1742-6596/1527/1/012030

[18] Öztürk, M.: Examining physical and mechanical properties of lightweight concrete with pumice and perlite, Master of Science Thesis, Tekirdağ Namık Kemal University, 2012. (Turkish) 
[19] Singh, M., Garg, M.: Perlite-based building materials - a review of current applications, Construction and Building Materials Volume 5, Issue 2, June (1991) pp. 75-81. https://doi.org/10.1016/0950-0618(91)90004-5

[20] Pichor, W., Janiec, A. J.: Thermal stability of expanded perlite modified by mullite, Ceramics International Volume 35, Issue 1, January (2009) pp. 527-530. https://doi.org/10.1016/j.ceramint.2007.10.008

[21] Zukowski, M., Haese, G.: Experimental and numerical investigation of a hollow brick filled with perlite insulation, Energy and Buildings Volume 42, Issue 9, September (2010) pp. 1402-1408. https://doi.org/10.1016/j.enbuild.2010.03.009

[22] Todor, D. N.: Thermal analysis of minerals, Abacus Press, 1976. 